International Journal of Indonesian Philosophy \& Theology

2020, Vol. 1(2): 91-104

(C) The Author(s) 2020

p-ISSN: 2722-8894; e-ISSN: 2722-8886

DOI: $10.47043 /$ ijipth.v1i2.9

https://aafki-afti.org/ijipth

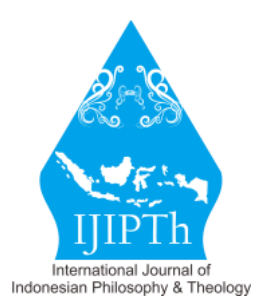

\title{
Mission and Engagement of The Vincentians to Priestly Formation in Indonesia: A Historical-Theological Revisit
}

\author{
Lorentius Iswandir ${ }^{1}$, FX Eko Armada Riyanto ${ }^{2}$ \\ ${ }^{1}$ Theologische Fakultät Paderborn, Germany \\ ${ }^{2}$ Sekolah Tinggi Filsafat Teologi Widya Sasana, Malang, Indonesia \\ Email: 1iswandircm@yahoo.com, fxarmadacm@gmail.com
}

\begin{abstract}
This paper explores historical engagement in priestly formation in Indonesia by the Vincentians, the Catholic Religious Congregation, who has been sent to a mission in Indonesia (from the Netherlands) and erected the Diocese of Surabaya 1923. The paper outlines the Vincentian missionaries' theological understanding of mission and the importance of establishing minor and significant seminary to train the indigenous candidates for the priesthood to take care of their local churches. This study's methodology applies a historical approach to see the strategies of the Vincentians to develop the formation of priestly candidates related to the challenges of the times. From this study, we found that the history of the Catholic mission has a meaningful peak in the success of planting the Church as often produced in the mission and the formation of its local priests. The education of candidates for the priesthood is not just a form of apostolic work but is essentially a necessary part of the Catholic Church's mission. The Vincentians have carved a hard piece of mission apostolates in establishing the Diocese of Surabaya with its charismatic works and the education of its laymen until today and especially in the continual engagement in the priestly formation in Indonesia with its changing challenges. The excellent form of the Catholic priests is essential to the mission, as the candidates will be the future leaders of the local Church and the preachers of the Gospel wherever they are sent.
\end{abstract}

Keywords: Mission; Priestly Formation; Indonesian Vincentians; Major Seminary; Diocese of Surabaya.

\begin{abstract}
Abstrak: Fokus paper ini ialah sejarah keterlibatan dalam pendidikan para calon imam oleh para Vincentian, sebuah kongregasi religious Katolik yang sejak tahun 1923 diutus misi ke Indonesia (dari Belanda) dan mendirikan Gereja Keuskupan Surabaya. Paper menguraikan pemahaman para misionaris tentang teologi misi dan pentingnya mendirikan seminari-seminari menengah dan tinggi untuk mendidik para calon imam pribumi yang akan mengurus Gerejanya sendiri. Metodologi studi ini menampilkan pendekatan historis untuk menyimak strategi para Vincentian dari zaman ke zaman terkait dengan tantangan yang berkembang dalam formasio para calon imam. Dari studi ini saya menemukan bahwa sejarah misi memiliki puncak bukan hanya dalam kesuksesan penanaman Gereja sebagaimana menjadi ciri khas karya misi Gereja Kristen, melainkan juga dalam formasio para calon imam lokalnya. Pendidikan para calon imam bukan hanya sekedar sebuah bentuk karya kerasulan, melainkan terkait erat dengan karya misi Gereja Universal. Para Vincentians telah mengukir kerja keras misi tidak hanya dalam pendirian Gereja Keuskupan Surabaya dengan karya-karya kharismatisnya dan pembinaan para awamnya hingga saat ini, melainkan juga terutama dalam karya Pendidikan calon imam dengan segala tantangannya yang terus berubah. Pendidikan para calon imam esensial dalam misi, sebab mereka akan menjadi para pelanjut dan tokoh Gereja Katolik di Indonesia dan pewarta Injil dimana pun mereka diutus.
\end{abstract}

Kata kunci: Misi; Pendidikan Imam; Vincentian Indonesia; Seminari Tinggi; Keuskupan Surabaya.

\section{Introduction}

The Catholic Church is present in the world and lives among the people who struggle for a good life and long for salvation. The church expresses its concern for the world with all its dynamics and challenges. "The joy, hope, sadness, and anxiety of people, especially those who are poor or suffering. These are the joys, hopes, sorrows, and worries of the followers of Christ" (GS Art. 1), as the Second Vatican 
Council declared. The church should be the "sacrament of salvation" for the world (AG Art. 1), proclaim God's kingdom and the message of salvation, and take the suffering people closer to concrete salvation. The Catholic Church must assume the responsibility and offer integral salvation of the world. With this theological understanding of nature, the mission, the church should prepare people who devote themselves to missionary work, especially priests, to carry out their services both within the church and society. The question is, how should the candidates for the priesthood for this ministry be trained?

We want to deal with how the Vincentians have offered priests' formation in Indonesia during the missionary period and how they carry it out today. The Vincentians started to engage information of the local candidates to support their missionary work and the Indonesian Church in the future. Furthermore, the trained natives of the Vincentians take over the further training of the priestly candidates. The church context in Asia or Indonesia often turns out to be different from that in Europe or Germany. Dialogue with other religions about harmony in living together or Catholics' participation in building the state is more topical in Indonesia.

Vincentian priesthood formation aims to lead candidates to follow Christ according to their vocation, "who proclaims the Good News to the poor" (Die Konstitutionen, 1984). How do they realize God's call during the missionary period, and what are today's formation challenges? How do they perceive the needs of the Church and society? Another important question is also to what extent the local churches can go in their way in the formation of priests. But it would be better here to do a review of the historical resources of the Vincentian mission in Indonesia.

\section{Review of the Historical Sources}

One of the main struggles in historical research of the Vincentians in Indonesia is to find valid sources as many as possible. In this historical review, we classify resources into two groups, i.e., archives and publications:

Archives: (1) St. Jozef Helden-Panningen Archive is located in the house of the Province of the Netherlands. Panningen keeps letters and documents of the missionaries of Indonesia. (2) Santa Agatha Archive. Santa Agatha is a "Klooster" (contemplative monastery) that becomes a consortium of the Dutch religious congregations. It is one of the collaborations to save the historical resources of the religious orders following the declining number of vocations in the Netherlands. (3) Maison-mere Archive, Paris. The House of the Generalate of the Vincentians was in Paris until the early 1960s. Paris becomes one of the most essential Archives that kept documents from the Vincentian missionaries. In Paris, we found Tien Jaar (1945-1955), a small book that shows how the Church of the Diocese of Surabaya was rebuilt after World War II. (3) Roma Curia Generalizia Archive. The Roman Curia kept documents and letters of missionaries to the Father General. (4) Roma Collegio Leoniano Archive. Leoniano kept documents and letters from the Italian missionaries who first arrived in the Diocese of Surabaya in 1964. Leoniano stored valuable documents of the negotiations from Mgr. J. Klooster CM, Bishop of Surabaya with the Province of Rome, and Italian missionary documents from Indonesia. (5) Kepanjen Archive. The house in Kepanjen street, Number 9 at Surabaya, is the first house of the Vincentians, which is now the Provinsialate. In Kepanjen, there is the manuscript of the "Historia Stationis Soerabaiae ab anno 1810 ad annum 1890" (History of the Surabaya parish from 1810 to 1890). (6) The diocese of Surabaya archives many letters and valuable documents necessary for understanding the history of the Diocese. However, perhaps it is also limited because various personal communications from missionaries could not have a "copy" in the Diocese. 
Publications and Documents: (1) Annales, Catalogue, Jaarbook, Missie Almanak, and various publications journals/magazines, books, articles, etc. (2) Memoire could be the unpublished writings, the testimony of missionaries. (3) St. Vincentius A Paulo: Missietijdschrift der Lazaristen is a mission magazine of the Vincentians Fathers first published in 1911 (its publication began in December 1910) in Helden-Panningen, Netherlands (for some time later its publication moved to Nijmegen). This magazine is essential for the history of the Mission of the Vincentians of the Dutch Province in Indonesia. In 1928, the title changed to St. Vincentius A Paulo. Tweemaandelijksch Tijdschrift van de Congregatie der Missie Lazaristen. Then in 1934, the title became St. Vincentius A Paulo. Tweemaandelijksch Tijdschrift van de Lazaristen. The magazine itself was small in terms of format, but it carved an enormous pilgrimage of the Vincentian missionaries, especially in Indonesia.

(4) The full title is Missiefront: Missietijd-schrift der Lazaristen en Dochters der Liefde (Missiefront Mission Magazine Romo-Romo Lasaris and Princesses of Love). First published in 1946, to replace St. Vincentius A Paulo: Tweemaandelijksch Tijdschrift van de Lazaristen which ceased in 1940 due to the raging World War II in Europe and the Asia Pacific. In the early forties to fifties, Missiefront was filled with interesting sharing from missionaries. (5) The Catholic weekly tabloid, De Katholieke Gids, began its publication on November 11, 1928. That year coincided with the establishment of the Prefecture of Surabaya. The Japanese occupation ceased publication in March 1942. This weekly publication also contained the first news about building the minor seminary in the Diocese of Surabaya, which never happened until 1948. (6) Annales de la Congregation del la Mission et de la Compagnie des Filles de la Charité first published by the Generalate (in Paris, Rue de Sevres, 95). It was first published in 1834/1835. From its title, we can imagine that this magazine contains everything related to the Vincentians' lives and missionary activities. Annales includes reports of missionaries in essential years in the history of Vincentians in the diocese of Surabaya. We are informed about the establishment of the pastoral centers being carried out and the difficulties and concerns of the missionaries at that time.

(7) Jan Haest, CM - Ten Years of Mission (1945-1955), Tien Jaar Missie. Surabaya, 1956, 33 pages of manuscripts. The historical information from Jan Haest's book is precious. Because it is the first writing about the history of the Prefecture and then vicariate of Surabaya (1942) during the Japanese occupation. This paper also reveals essential preliminary information regarding establishing the Surabaya Prefecture and Vicariate with all intentions of setting the mission centers and the start to search the indigenous Vocations. The book describes the state of development over the ten years since the Vicariate of Surabaya was "destroyed" by World War II (1945) in detail. The same author, Jan Haest CM, also published the paper De Geschiedenis der R.K. Kerk te Soerabaja van 1906-1931 (12 pages). This paper mainly contains the Jesuit Fathers' mission period in Surabaya (1859-1923), which in 1923 was handed over to the Vincentians. As reported at the time, the areas of Mission were Surabaya, Kediri, Rembang; there were two churches in Surabaya, of which the Church of the Sacred Heart of Jesus was under repair. And four chapels in and outside the city of Surabaya; there were very few Javanese Catholics, only 40 people, the rest were European or Indo-European Catholics. The paper was in the series publications of De Katholieke Gids in 1934.

(8) Missie Almanak voor Nederlandsch Oest-Indië is what we now call the Catholic Church's Manual. From the book of The Almanac, we see and track down the Vincentian missionaries' work where and in what year in the Surabaya Prefecture. The book De Katholieke Missie in NederlandschIndië. Jaarboek has the same meaning and function as the Almanac. 
(9) Catalogus of the Vincentians (the Congregation of the Mission) is the annual book that published the missionaries' list with their address. And years of assignment with the identity of the calendar of the conference. Such as the year of ordination, the year of vows, etc. The catalog ceased during the war (1941-1946), continued to publish until now.

(10) Anton Bastiaensen CM, Kreus en Kris (1934). This book is perhaps one of the most impressive first reports on the "new baptisms" in Blitar. In the context of the history of mission work at that time, the new baptisms were not only the pride of the missionaries but mostly the beautiful fruits of the Mission in the Diocese of Surabaya. The author, Father Anton Bastiaensen, was a missionary who was very active in establishing many catholic communities in the region of Blitar.

(11) Piet Boonekamp CM, "History of the Catholic Church in the Diocese of Surabaya," in P.M. Muskens, ed., History of the Indonesian Catholic Church, Vol. 3b, Ende-Flores 1974, 949-999. This article systematically describes the state of the Vincentians' Mission from the beginning with an introductive description of the missionary journey of Johannes Gabriel Perboyre CM, the martyr saint in China, who stopped by for a month in Surabaya until the historical events of the 1970s. It is a historical account, which has the accuracy of historical sources and data.

(12) John Tondowidjojo, CM, Terj., Menapak Jejak Misionaris Lazaris. Dalam Rangka Kongregasi Misi 75 Tahun di Indonesia (Tracing the Footsteps of the Lazarist Missionaries:the Anniversary of the 75th of the Congregation of the Mission in Indonesia), five volumes, Surabaya 1995. This book contains merely translations of the selected articles taken from St. Vincentius A Paulo. Missietijdschrift der Lazaristen and Missiefront from 1923 onwards.

(13) F.X. Armada Riyanto, CM, 80 Tahun Romo-Romo CM di Indonesia (the 80th Anniversary of the Vincentians in Indonesia (2003) and Sejarah Hati Misi CM Indonesia (History of the Heart and Mission of the Vincentians in Indonesia [2014]), which was presented on the occasion of the 90th of the presence of the Vincentians in Indonesia. The books emphasize the historical account of the missionary activities of the Vincentians and especially its implications for charismatic works in the future. Riyanto also deals with the history of the priestly formations of the Vincentians in collaboration with the Carmelites in 40 Tahun STFT Widya Sasana (or the 40th Anniversary of Widya Sasana School of Philosophy and Theology), written by Armada Riyanto CM, Edison Tinambunan O.Carm, and Rafael Isharianto CM, published by Widya Sasana press 2011.

\section{The Missionary Experience of the Vincentians in Indonesia}

\section{The Foreign Missionaries Preach the Gospel in Surabaya}

There were three groups of missionary Vincentians doing missions on the Archipelago of Indonesia: Dutch, Italian and French. The Dutch Vincentians first came to the Archipelago in 1923, then the Italians in 1964, and it wasn't until 1976 that the French reached Indonesia. The first two worked in a region in East Java whose center was Surabaya, later known as the Diocese of Surabaya. The territory assigned to the Vincentian missionaries extended from the western part of eastern Java to the east part of central Java with 26,461 square kilometers (Boonekamp, 1974). There were around six million residents. Of them, more than 5.5 million were Javanese, 60,000 Chinese, and only 15,000 European. At that time, there were about 4,600 Catholics, 40 of whom were Javanese. Before it was assigned to the Vincentian, the area was served by only two Jesuits. 
How did the Vincentians get the mission to Surabaya? St. Vincent de Paul, the Founder of the Congregation of the Mission, quotes in the General Rules and Constitutions for the Congregation he founded what the Apostle Paul says: "How should anyone preach when he is not sent?" (Rom 10:15) (Die Konstitutionen, 1658). The Vincentians only operate the mission when they are sent. The Founder adds that the Vincentians must go to the mission only when instructed to do so by the visitor (Konstitutionen, 1984) or the immediate superior. To send the members to a foreign mission, the visitor must contact the superior general (Konstitutionen, 1984). Both the visitor and the only general must cooperate with the ministries of the local church. The mission is all about the relationship between the religious order and the church's representative within the ecclesiological context, in the sense that the fulfillment of the Vincentian mission means the completion of the church's mission at the same time. The notion of the fulfillment of the Vincentian mission means accomplishing the church's mission at the same time. They bear the name of the church in their service.

When the Dutch missionaries began their mission in Indonesia in 1923, they were sent by the visitor, Henri Romans CM. The broadcast was based on a Prefect of Propaganda Fide Cardinal Willem Marinus van Rossum CSsR in Rome for the Superior General François Verdier CM in Paris. In 1922, Cardinal van Rossum invited the Vincentians of the Dutch province and sent them to a mission in East Java (Surabaya, Kediri, and Rembang) to replace the Jesuits. The latter had been in this area since 1859 . The mission areas still belonged to the Vicariate of Batavia, whose Vicar Apostolic was Msgr. E.S. Luypen SJ. In early 1923, the Superior General sent an annual newsletter to all Vincentian provinces worldwide, including a report on the announcement of the mission to Java. The Dutch province accepted this mission invitation. The visitor first sent his five confreres Theophile de Backere CM, E.E. Sarneel CM, Jan Wolters CM, Th. Heuvelmans CM and C.A. Klamer CM. On June 6, 1923, they journeyed on the ship "Johan de Witt" from the port of Genoa, Italy. After three weeks on the high seas, they arrived in Batavia on June 30. They continued to Surabaya, where the French Vincentian - the martyr Johannes Gabriel Perboyre CM - stopped over 1835 for a month on his missionary way to China.

Apart from the Europeans, there were also different ethnic groups in this mission area, namely the Javanese, Madurese, Chinese, British Indians, and Arabs. At that time, there was no common language, and each group had its language. The Europeans spoke Dutch or English, the Javanese people Javanese, Chinese Mandarin, Madurese spoke Madurese language. Missionaries were sent to these peoples. The native language was a great challenge for them on the mission. Learning the local language was a must if you wanted to win souls to God. Hence, language is an essential tool of the mission.

Another challenge for the Dutch missionaries was that the Dutch were the colonial masters for the natives. The missionaries had their Dutch nationality, with which the locals-only associated them with the cruel colonialism. On the one hand, they preached the peaceful gospel message to the local people; on the other hand, according to their nationality, they remained Dutch, who were the colonial masters who were opposed by the people. The colonial government supported the church's missionary work. It was worth it since the travel fund of the church mission was supported by the government. Based on the Radical letter, the missionaries had the right to receive salary and protection (Riyanto, 2014). But, the intervention of the colonial government in church affairs was inevitable. Because the missionaries also had the duty to observe the rules set by the colonial government. The missionary activities were not allowed to deviate from colonial interests. The colonial government could designate the missionaries, accept them, or reject them, appoint them or remove them. 
There was often a conflict of interest between the commercial-political level and the spiritual cause. The attitude of the church missionaries in the context of colonialism often showed an ambivalence between the interest of their nationality in mission and the needs of the local people, politics, and religion, colonial power and pastoral tasks, the worldly pursuit of money, gold, and glory; and the spiritual service in self-sacrifice for God. The colonized expected a spiritual message from the missionaries and precisely a better life, economically, technically, and educationally. Therefore, the church tried to break away from the connection with colonialism. She wanted to be seen much more as a minister of the gospel than an employee of the colonial government.

From 1923 to 1968, the Dutch Province of the Vincentian sent 73 confreres to Indonesia. They served in the churches in Surabaya and visited indigenous non-Christians who lived in rural villages. The missionaries went abroad because of their faith in their own country. Out of an apostolic spirit, they left their friends and relatives to go to missionary land, spread the Christian faith there, and preach the gospel of God's kingdom to the people. In mission, the Vincentian realized their calling, as St. Vincent de Paul said about the missionary calling to follow Christ who went from place to place "to win souls to God" (von Paul, 2006). The concrete form for this mission is missionaries going to people to teach them about religion, convince them of the meaning of life, baptize catechumens, build schools, establish churches and social organizations, build clinics and hospitals, and much more. The gospel, i.e., the good news, should be realized in everyday human life.

\section{A fundamental shift: from "object" to subject of the Mission}

When the Vincentian missionaries arrived in Surabaya in 1923, only 40 Javanese were Catholic. That is why the superior of the missionary group "superior mission." de Backere CM said in his letter this year: "We have to convert seven million pagans" (Riyanto, 2003). Five years later, the mission areas (Surabaya, Cepu, Madiun, Mojokerto, Kediri, and Blitar), on February 15, 1928, were joined to an Apostolic Prefecture - the number of Catholics was 10,345, among them 511 people who were not Europeans. The number of native Catholics has continued to increase over time. On February 11, 1942, the prefecture was elevated to the Apostolic Vicariate, and on January 3, 1961. Its status was changed to the Diocese of Surabaya.

Piet Boonekamp CM presented a statistic in his essay that between 1948 and 1960. There was a shift in the composition of the number of Catholics. In 1948 there were around 17,000 European Catholics, while the Indonesian Catholics were only about 2,000. In 1960 the number of European Catholics fell to approximately 1,000, while the number of Indonesian Catholics rose to around 22,000 (Boonekamp, 1974). In his essay, Boonekamp CM added that 73 the Dutch Vincentians arrived in Indonesia as missionaries between 1923 and 1967, of which only 18 were missionaries left in 1972. In contrast, the number of Indonesian priests rose this year to 26 Vincentian and three diocesan priests.

This significant change could not be separated from the socio-political situation in Indonesia. The situation of the Second World War and the subsequent proclamation of Indonesia's independence on August 17, 1945, contributed to Indonesians' lives in general and the church in particular. After the country's declaration of independence, the recognition of its sovereignty on December 27, 1949, and after the establishment of the church hierarchy on January 3, 1961, the idea of "Indonesianisasi" (“Indonesianization") arose (Boelaars, 1991).

With Indonesianization, a transformation process is meant first, the general goal of which was and is aimed at the interests of Indonesia, politics, and economy, and religion. The official language was 
changed, workers and politicians were replaced. As a result of this, the Indonesian government no longer allowed the foreign missionaries to extend their residence permit in Indonesia.

On the one hand, the number of Catholics has increased rapidly. On the other hand, the number of priests has decreased drastically because of the missionaries' return to their homeland. Many dioceses, especially outside the island of Java, had a severe shortage of priests, so many areas were only visited by a priest once or twice a year. "Since the 1980s, the Indonesian Bishops' Conference has made several attempts on its' ad limina visits' to Rome, given the serious shortage of priests in Indonesia. To obtain the approval of Rome from among the numerous and well-trained catechists tried and tested men' (viri probati) to ordain priests, with whom she hoped to find a solution to the personnel problem that was adequate for the pastoral needs in Indonesia" (Evers, 2003). During the visit, the bishops conveyed two other concerns, first of all, the possibility that the laypeople were permitted to donate the sick's anointing. Second, the members of the Indonesian Bishops' Conference should be given the authority to appoint lay people to be qualified witnesses to officiate with the usual two witnesses at marriages (Boelaars, 1991). Permission was never granted by the Roman Curiae or Pope John Paul II. Since then, there hasn't been much discussion about it to this day.

The Church in Indonesia or the Diocese of Surabaya is developing. Today there are more than 150,000 Catholics and 101 diocesan priests in this diocese. Various men and women religious communities work there. They support the work of the church in different areas: education, health, social charity, pastoral accompaniment, retreat houses, and much more.

The Vincentian community in Indonesia is also developing. In 1950 it became a vice-province, and in 1958 it was raised to an independent province. So, you can even say that it's not just the Vincentians in Indonesia, but the Vincentians of Indonesia. There are 102 priests and one brother of the Vincentian of Indonesia, including 2 Italians and 1 French. These three have already accepted Indonesian citizenship. The Indonesian Vincentians no longer work only in the Diocese of Surabaya. On the island of Java, they still work in the Malang diocese, East Java, and the Jakarta archdiocese. They also answer inquiries from other biscuits outside of Java. On the island of Kalimantan (Borneo), they work in the Diocese of Banjarmasin, South Borneo, and West Borneo in the Diocese of Pontianak in the Diocese of Sintang. On the island of Papua, they serve the Diocese communities of Manokwari-Sorong, West Papua, and in the Archdiocese of Merauke, Papua. To respond to the universal church's needs, the Indonesian Vincentians also send their members abroad: Papua New Guinea, Solomons Island, Taiwan, Philadelphia, Bolivia, and Suriname. The history of the Vincentians shows that the church is missionary (von Paul, 1659). The missionaries always remain in the church for the spirit of mission; in Indonesia, the missionaries became the missionaries.

\section{Formation of priests in the missionary times and in the present}

\section{Priestly formation for locals during the missionary period}

The fundamental change from Vincentians in Indonesia to Vincentians of Indonesia and foreign missionaries to the indigenous ones did not occur if local priests would not be trained. The Superior of the missions and at the same time the first Prefect of Surabaya (1928-1938), Msgr. Theophilus de Backere CM tried with his motto "parare vias domini" to pave the way for local priests' training. Because he believes the Catholic Church must take root in Java through local priests. And the future of the mission depends heavily on training priests for local people. This spirit is the mission of the Church 
by Pope Benedict XV in his apostolic. The letter "Maximum Illud" on November 30, 1919, and Pope Pius XI in his encyclical "Rerum Ecclesiae" on February 28, 1926.

In his apostolic letter, Pope Benedict XV, with his words to those who, as bishops or apostolic vicars or prefects, preside over the ecclesiastical mission work or head of mission, that "they educate and train servants of the sanctuary from among the people among whom they reside. This is mainly the future of new churches (Benedikt XV, 1919)." The Pope gives a reason that the native priest, who is connected to his people through his ancestry, his mental disposition, his feelings, and his aspirations, has a beautiful power, their spirit, to teach the faith. For this, it is necessary to train and practice the local clergy well. Pope Pius XI reminds us of the importance of the task of educating indigenous clergy. It is hoped that indigenous young people will be adequately instructed and trained to attain priestly dignity and convert their tribesmen to Christianity (Pius XI, 1929). They should be carefully brought up in holiness and in an apostolic spirit who works with great zeal for their brethren's salvation.

Because of World War II and the struggle for the independence of Indonesia, the establishment of a seminary in Surabaya did not take place until 1948. There were eight seminarians at the time. They lived in a rectory. One of the teachers, Jan Wolters CM, reported in his 1950 article: "There has long been a plan for the culmination of all missionary work, namely, priestly formation for the local population" (Wolters, 1954). He said that the great pioneer, the late Msgr. de Backere CM, who saw the future of the mission in Surabaya and provided land next to the new church in Kediri. The seminary foundation is seen as the high point of the missionary work because the missionaries built many schools, churches, and chapels beforehand. With the establishment of the seminary, the Catholic Church should be independent with her local priests.

The seminary was moved from Surabaya to Garum in 1958. In this place, there was a minor seminary for the diocese and a novitiate for the Vincentians. At that time, there were no theological books in the mother tongue (Indonesian language), so that the Candidates had to follow and learn the Dutch language quickly. Language teachings were taken very seriously in seminary; the native languages Indonesian and Javanese and foreign languages such as Latin, Greek, Dutch, English, French, and German were taught (Wolters, 1954). Spiritual education also remained essential. When they had completed the minor seminary, they went to the major seminary for the secular priests' candidates in Yogyakarta, the central Java, and the Vincentians in Rembang, the central Java. In Rembang, they studied philosophy for two years and then theology for four years in Panningen, Netherlands. When there was a conflict between the Indonesian government and the Netherlands over West Papua, the Candidates had to move. The Vincentians sent their candidates to Perryville, USA, and others to Genoa, Italy, and Eastwood, Australia. Since 1962 the Vincentian candidates have been trained in the Kediri Major Seminary. The major seminary moved to Malang in 1971 and built the so-called Widya Sasana School of Philosophy and Theology.

The missionaries prepared the independence of the local church by establishing priestly formation for the local people. With great courage, they embarked on the path of independence for the Church of Indonesia. The church's mission does not cease after the foreign missionaries died but continue with the same missionary zeal to this day through newly trained local missionaries.

\section{Priestly formation for the Indonesian Vincentian today}

Since 1971 the Major Seminary of the Indonesian Vincentians has been located in Malang, East Java. Territorially, this place belongs to the area of the diocese of Malang. There is a long collaboration 
between the Vincentians and the Carmelites, who has built the joint priestly formation to establish a school of philosophy and theology known as Sekolah Tinggi Filsafat dan Teologi (STFT) Widya Sasana Malang was realized.

The STFT is open to further developments, i.e., The cooperation does not only exist between the Vincentians and the Carmelites, but today it cooperates with other religious orders (approx. seven for men and ten for women), and with a further 12 dioceses and additional laypeople. These religious orders and dioceses send lecturers with a teaching assignment and Candidates as students in STFT. The students are from seminaries and the ranks of religious sisters and laypeople with other religious affiliations. The STFT offers courses that combine philosophy and theology at an academic level; 4 years are set for the bachelor's course and a further two years for the master's course; and since 2019, there is also a doctorate program of theology, which is the first set up in the Catholic Church in Indonesia. This means that the priestly candidates' philosophy or theology is not offered at different levels, but the two subjects are combined in the courses within the six years (Codex, 1983). Here, the Candidates are scientifically and academically trained in various philosophical and theological disciplines to acquire the necessary knowledge and exercise a spiritual office in the future or fulfill "the community's mission" (Konstitutionen, 1984). After completing the bachelor's degree, an annual internship in pastoral service in a parish is followed.

For the Vincentian Candidates, there is also special training outside of the STFT's scientific program, e.g., service to the poor in keeping with the Vincentian charism. There is also an annual internship for the categorical service, which focuses on the Vincentian charisms. The general educational path of the Indonesian Vincentian Candidates is as follows:

Table 1. The general Educational Path of the Indonesian Vincentian Candidates

\begin{tabular}{|l|l|l|}
\hline Course & Duration & Program \\
\hline $\begin{array}{l}\text { Before the inner seminar } \\
\text { (postulate) }\end{array}$ & 1 year & $\begin{array}{l}\text { - introductory vocation and discipline of regular life. } \\
\text { - Practice praying, learning, and working in a community. }\end{array}$ \\
\hline $\begin{array}{l}\text { The Inner Seminar } \\
\text { (Seminarium Internum) }\end{array}$ & 1 year & $\begin{array}{l}\text { - Get to know the Vincentian charism and take part in } \\
\text { spiritual exercises. } \\
\text { - To share the life of the poor through the practice of } \\
\text { "immersion." }\end{array}$ \\
\hline The Bachelor & 4 years & $\begin{array}{l}\text { - Gathering scientific knowledge of philosophy and } \\
\text { theology. - Weekly school lessons } \\
\text { - Pastoral service in a parish and service for the poor. }\end{array}$ \\
\hline The parochial internship & 1 year & $\begin{array}{l}\text { - ordination as a lecturer and acolyte. } \\
\text { - Look after different groups of the congregation in a parish } \\
\text { and exercise the pastoral service. }\end{array}$ \\
\hline The categorical internship & 1 year & $\begin{array}{l}\text { - service in various fields of work of the Vincentians. } \\
\text { - Deepening Vincentian spirituality. } \\
\text { - Take eternal vows (chastity, poverty, obedience, and } \\
\text { constancy) (Konstitutionen, 1984). }\end{array}$ \\
\hline The master & 2 years & $\begin{array}{l}\text { - Deepening scientific knowledge of theology. } \\
\text { - Exercise deacon ordination and ministry of the diaconate. }\end{array}$ \\
\hline
\end{tabular}


They postulate only is meant only for those who are not previously trained in a minor seminary. After completing the master's degree and at least six months after being ordained a deacon, the alumni may be ordained a priest.

There are goals and strategies for applying the five dimensions of formation at each stage, namely human maturity, spiritual and intellectual formation, apostolic, and community life (Ratio Formationis, 2016). It is also essential to convey the spirituality of the five Vincentian virtues, namely Simplicitas (simplicity), Humilitas (humility), Mansuetudo (gentleness), Mortificatio (mortific ation), and Zelus animarum (zeal for the soul). The goal of formation is to follow Christ, who proclaims the good news to the poor. To this end, the Vincentians should initially see themselves as missionaries; Becoming a priest or brother is secondary (Ratio, 2016). The congregation members should engage in this missionary vocation and be ready to walk the path that the universal church shows. In unison, the Candidates should also be trained to respond to the Holy Spirit's call is the reality of Indonesia and the local church's demands (Norma, 2006). The Church of Indonesia pays attention to cultural plurality and promotes harmony with other citizens who belong to other religions. Furthermore, poverty and the gap between rich and poor are the facts that need to cope with. Communication and dialogue are the central issues that concern the church on a long-term basis, and they are also part of the current priestly training in Indonesia.

\section{Challenges in Priestly Education Today}

The 21 st century is characterized by rapid technological developments and changes, which impact people, society, and the church. This epoch can be described with the keywords "globalization", "networking", "automation", "social media", "mobility", "flexibility" and "age of freedom". These also affect the behavior of the Candidates in the formation of priests. For example, they spend a lot of time on the computer, which they use for work and social media, e.g., Facebook and Instagram, or searching on YouTube and other portals. These can be addicting because if you use them until late at night and go to bed late, they lack the concentration in the morning that they urgently need for spiritual events such as early prayer, meditation, and the celebration of the Eucharist. They also carry their tiredness into university lessons and lose their passion for learning. They have no time for the virtual world with social media to carry out their work and tasks with care. They are becoming increasingly individualistic in their world. As a result, they lack sensitivity to the real world of the people around them (Compare Abraham, 2020; Kilby, 2020; Hoeft, 2020).

The form of priestly formation cannot be separated from the influence of this situation. In contemporary education, one cannot use a top-down or command method, but the bottom-up dialogue and greater recognition. In the preamble of the Ratio Formationis 2016 of the Congregation of Mission, inductive thinking is mentioned. Individual circumstances, experiences of the individual, and contexts play a more significant role in determining truth, meaning, and responsible action. It also highlights a tendency towards relativism, which calls into question the possibilities and the values held by the church. This tendency also impacts the candidate's willingness, e.g., deal positively or negatively with a longterm or lifelong commitment to celibacy.

In the local context, the Vincentian Indonesian seminary formators name the reality of plurality as a major challenge of current education (Ratio, 2016). They show an example in everyday life that the Candidates or formats come from different cultural and regional living spaces. In the past, most of them came from the island of Java, but now they also come from other islands such as Sumatra, Nias, Borneo, 
Celebes, and Papua. Each region or island of Indonesia has its own different cultures, languages, customs, and expressions of religion. This cultural diversity is a great wealth and should become part of developing the spiritual, intellectual, and community life in every training stage.

The context of plurality is a challenge in the formation of priests of the Vincentian and the whole Church of Indonesia. There is great religious and ethnic diversity in Indonesia. The state officially recognizes six religions. These include Islam, Protestantism, Catholicism, Hinduism, Buddhism, and Confucianism. The order corresponds to the population's proportions: Muslim 87.2 percent, Protestant 7 percent, Roman Catholic 2.9 percent, Hindu 1.7 percent, other religions 0.9 percent (including Buddhists and Confucianists), not specifically 0.4 percent. There are more than 350 ethnic groups in Indonesia. One of the largest ethnic groups is the Javanese with 40.1 percent, then the Sundanese 15.5 percent, Malay 3.7 percent, Batak 3.6 percent, Maduresen 3 percent, Betawi 2.9 percent, Minangkabau 2.7 percent, Buginese 2.7 percent, Bantanese 2 percent, Banjarese 1.7 percent, Balinese 1.7 percent, Acehnese 1.4 percent, Dayak 1.4 percent, Sasak 1.3 percent, Chinese 1.2 percent (Houben et al. ii, 2015). Each ethnic group has its language, of which Javanese, Sundanese, and Malay are the three largest language groups. In this context, the church should deal with other religions and in connection with local cultures. Therefore, the professors' task is to convey a translation from European philosophy and theology and teach theology in this cultural and political context. Both the bishops' conference and a local bishop of Indonesia often reminds the parishes. And those responsible for pastoral or categorical services that the programs of parish activities in the society are based on the basic principles of the Indonesian state "Pancasila" (five principles) and "Bhineka Tunggal Eka" (unity in diversity) must be observed.

\section{Conclusion}

The priestly formation of the Indonesian Vincentians is now in the trained native Vincentians' hands with collaborators from other religious congregations and diocesans. Thanks to this training of priests, the local church's continuity is ensured, and the Christian faith can be rooted in the local culture. This is by the will of the universal church as set out in the Codex of Canonical Law."

The formation of priests is the specific missionary activity aimed to ensure that "the young churches are fully established, and the candidates are endowed with their strength and sufficient means with which they can carry on the work of evangelization" (Can. 786). The young churches should be increasingly independent "with their strengths," both personally and financially and organizationally, that is, their clergy, their religious and laity, as well as offices and institutions for the life of God's people (Mussinghoff, 1987). The Christian faith should also be rooted in social life and roughly embedded within the local culture. In his commentary, Heinrich Mussinghoff adds a thought of Oscar Stoffel about three criteria for a young church that has become independent, namely (1) self-determination, i.e., inculturation of the message and formation of a local clergy under a local bishop, (2) self-preservation, i.e., economic independence from the outside, and (3) self-expansion, i.e., own missionary activity of the particular church (Mussinghoff, 1987).

To fulfill the church's mission, the Vincentians are "sent out to do missionary work by the competent ecclesiastical authority" (Can. 784). The law of the church defines the term missionary more clearly in the narrower and more specific sense. "Not the inner criterion of the vocation to this service by God (AG Art.23) and the personal suitability [...] is mentioned, but the outer and formal criterion of the canonical mission (canonica missio), the cooperation with the local competent ecclesiastical 
authority in the mission country and the communion with the Universal Church (communio)" (Mussinghoff, 1987). The Vincentians must first cooperate with the highest management of the missionary work, namely the Pope or the bishops' college (cf. Can 782). Hierarchically, they are the main persons in charge of the church mission. The Canon does not mention other responsible persons or their representatives. However, this does not mean that the Pope himself coordinates it to appoint, transfer, and distribute the missionaries' personnel. There is a papal body that organizes missionary tasks. It was made by Pope Gregory XV and founded in 1622 as the Congregation "Propaganda Fide," which today bears the name "Congregatio pro-Gentium Evangelizatione" (the Congregation for the Evangelization of Peoples).

Both the Dutch then and now Indonesians are missionaries, contributing to the church's work of evangelization. The natives are missionaries and the congregations with their tasks as missionaries because the whole church is missionary by nature (cf. Can. 781). The training of priests plays a major role in it. The Vincentian take part in the preparations for the future church's offices of Indonesia. The focus is on the fact that the academic training achieves a serious and systematic contextualization. It must find a relationship to "the requirements of the place and time [and] the corresponding culture" (Can. 248). Because the Indonesian citizens are shaped till this day by the history that Christianity is a foreign religion for them and its theology is very European. Inculturation is a central point in the Christian faith. The Candidate should also have "sufficient knowledge of the culture in which they will later work pastorally" (Althaus, 2018). By connecting themselves to the local culture - language, history, traditions, art, values, world views, and religiosity - the Gospel's proclamation will be at home surely (Compare Winkelmes, 2004; Cronshaw, 2016).

The Indonesian Vincentian's priestly training takes ten years after the minor seminary, which consists of a year of postulate, a year of novitiate, two years of pastoral internship, and six years of studies in Higher Education. According to Canon 250, the studies "have to last at least six years in total, so that the time for philosophical studies is a full two years, for theological studies a full four years." According to R. Althaus, the six years of study do not necessarily have to be completed at the same educational institution (Althaus, 2018). In Indonesia, the system applies that philosophy and theology are combined in six years of study. The question arises whether an open interpretation of Canon 250 is permissible, i.e., whether the time frame for philosophical studies must be two years, for theological studies four years, or whether it can be made more flexible. A comparison with the German-speaking area, where the degree (Magister) can be obtained after five years, shows that the duration and the system of the studies can be designed more flexibly (Compare Strange, 2016).

\section{References}

Abraham, S. (2020). Formation in the postmodern seminary. Teaching Theology \& Religion, 23(2), 64-74. doi:10.1111/teth.12537

Althaus, Rüdiger. (1984). 55. Lfg. Codex (2018), in: LÜDIKE, Klaus (Hg.): Münsterischer Kommentar zum Codex Iuris Canonici, Essen seit, 232-264.

Benedikt XV, Papst. (1919). Maximum illud, in: http://www.kathpedia.com/index.php/Maximum illud (Wortlaut), abgerufen am 16.11.2020.

Boonekamp CM, Piet. (1974). Sejarah Gereja Katolik di wilayah Keuskupan Surabaya, in: MUSKENS, M.P.M. (Hg.): Sejarah Gereja Katolik Indonesia. Jilid 3b, Ende-Flores, 949-999. 
Boelaars OFM Cap, Huub J.W.M. (1991). Indonesianisasi. Het omvormingsproces van de katholieke kerk in Indonesië tot de Indonesische katholieke kerk, Kampen 1991.

Codex Iuris Canonici. (1983). Codex des kanonischen Rechtes, Kevelaer 2001 (lateinisch-deutsche Ausgabe mit Sachverzeichnis, Vatikan.

Cronshaw, D (2016). A Review of "Transforming Congregations through Community: Faith Formation from the Seminary to the Church." Religious Education, 111(4), 463-465. doi:10.1080/00344087.2016.1104225

Die Allgemeinen Regeln und Konstitutionen der Kongregation der Mission (1658), in: Konstitutionen und Statuten der Kongregation der Mission, Romae, 107-177.

Die Konstitutionen der Kongregation der Mission (1984), in: Konstitutionen und Statuten der Kongregation der Mission, Romae, 19-94.

Evers, Georg. (2003). Die Länder Asiens, in: GATZ, Erwin (Hg.): Kirche und Katholizismus seit 1945, Paderborn u.a. 2003.

Hoeft, J. (2020). Assessment of Formation and Assessment as Formative: A Response to Formation and the Postmodern Seminary. Teaching Theology \& Religion, 23(2), 75-77. doi:10.1111/teth.12544

Houben, Vinzent/Connley, Aleah. (2015). Indonesien. Figurationen von Vielfalt in Einheit, in: GUNNAR, Stange/ JORDAN, Rolf/ GROßMANN, Kristina (Hg.): Handbuch Indonesien, Berlin.

Kilby, K. (2020). Formation and deconstruction in the postmodern seminary: A response to Formation and the postmodern seminary. Teaching Theology \& Religion, 23(2), 81-83. doi:10.1111/teth.12542

Mussinghoff, Heinrich. (1984). 5. Erg.-Lfg. Codex (1987), in: LÜDIKE, Klaus/u.a. (Hg.): Münsterischer Kommentar zum Codex Iuris Canonici, Essen seit, 784-792.

Norma Kongregasi Misi Propinsi Indonesia. (2006). Surabaya.

von Paul, Vinzenz. (2006). In Coste CM, Pierre: Correspondence, Conferences, Documents, Volume X., Conferences to the Daugters of Charity vol 2.

http://via.library.depaul.edu/vinzentian_ebooks/35, abgerufen am 17.11.2020.

von Paul, Vinzenz. (2010). In Coste CM, Pierre: Correspondence, Conferences, Documents, Volume

XII., Conferences to the Congregation of the Mission vol. 2.

http://via.library.depaul.edu/vinzentian_ebooks/36. abgerufen am 18.11.2020.

Pius XI, Papst. (2029). Rerum ecclesiae, in:

http://www.kathpedia.com/index.php?title=Rerum_ecclesiae_(Wortlaut), abgerufen am 16.11.2020.

Ratio formationis propinsi Indonesia. (2016). Produced by the Study Days at Formators of the Vincentians of Indonesia in Prigen, East Java on March 1-3.

Ratio Formationis Congregationis Missionis. (2016). Promulgiert in Rom am 27. November 2014, https://cmglobal.org/en/vinzentiana-2014-n-4-eng/, abgerufen am 18. November 2020.

Riyanto, FX. Armada. (2014). Sejarah hati misi. 90 tahun CM di Indonesia. 50 tahun Misi CM Roma di Keuskupan Surabaya, Surabaya.

(2003). 80 Th. Romo-Romo CM di Indonesia. Kaleidoskop misi. Panorama peristiwa misioner. Album misionaris, Surabaya. 
Strange, R. (2015). Seminary formation: a case study from the Pontifical Beda College, Rome.

International Studies in Catholic Education, 7(2), 210-221.

doi:10.1080/19422539.2015.1072959

Winkelmes, M.-A. (2004). The Classroom as a Place of Formation: Purposefully Creating a Transformative Environment for Today's Diverse Seminary Population. Teaching Theology and Religion, 7(4), 213-222. doi:10.1111/j.1467-9647.2004.00211.x

Wolters CM, Jan. (1954). Seminari St. Vincentius di Surabaya, in: TONDOWIDJOJO, John: Menapak jejak misionaris Lazaris 1946-1953, Surabaya 1994, 320-326. 